\title{
The Loyalty of Accountants to FDI Firms in Thanglong Industrial Park - Creative Application in Economics Sociological Knowledge
}

\author{
Dr. Dang Huy Nguyen \\ Hanoi University of Business and Technology, Vietnam
}

\author{
Dr. Hong Linh Nguyen \\ Faculty of Social work, University of Labor and Social Affairs, Vietnam \\ Dr. Thi Thanh Nga Nguyen \\ Faculty of Accounting, University of Labor and Social Affairs, Vietnam
}

Dr. Duc Tai Do

University of Labor and Social Affairs, Vietnam

\begin{abstract}
s
This study was conducted to identify, evaluate and measure the attributes of accountants' loyalty to FDI firms in Thanglong industrial park. Based on literature review and the results of some interviews, 150 questionnaires were sent directly to accountants in FDI firms in Thanglong industrial park and were collected in 1 month. However, only 105 questionnaires were satisfactory and included in the analysis. The results of descriptive statistics, Cronbach's Alpha analysis, Independent T-test and ANOVA have identified and measured 6 attributes of accountants' loyalty which effect on accountants in the FDI firms in Thanglong industrial park. Based on the findings, some recommendations are given to improve the accountants' loyalty.
\end{abstract}

Keywords: loyalty, accountants, FDI firms

JED codes: M41, M40, O15

DOI: $10.7176 / \mathrm{JESD} / 10-20-06$

Publication date:October $31^{\text {st }} 2019$

\section{Introduction}

The more loyal employees that a company has, the more success and competitive advantages it can gain (Cooil et al, 2007). Yee \& Faziharudean (2010) suggest that the loyalty of employees has a great influence on 3 aspects of profitability: service quality, customers' satisfaction, and customers' loyalty. A company that has greater loyalty among employees, customers and shareholders will create more profit (Foster et al, 2008).

FDI firms are important elements of an economy. They make a contribution to the increase of the state budget by paying taxes and thus, prevent the situation of state budget deficit. They create a competitive environment that promotes economic and trade development. They create a good condition for workers and managers to learn management experience from other countries and to have more chances to get the job, etc. However, in recent years, with changes of the economy, FDI firms as well as FDI firms in Thang Long industrial park in particular encounter many challenges, especially in human resources which includes accounting personnel. Human resources in the accounting and auditing sectors now form two types: mediocre human resources and high - quality human resources. Mediocre human resources account for a large number; meanwhile, high quality human resources account for a very low rate (Phan, 2016). Besides, FDI firms have poured a large amount of money on attracting and retaining outperforming accountants. Therefore, it is necessary to build a team of accounting employees with loyalty and high qualifications.

The objective of this study is to identify, evaluate and measure the component attributing accountants' loyalty to FDI firms in Thanglong industrial park. Thereby, suggesting some recommendations for accountants and FDI firms to build effective human resource development strategy.

\section{Literature Review}

Employees' loyalty is defined as how much a person has an attachment to an organization (Buchanan, 1974). According to Baleman \& Strasscr (1984), loyalty is a multidirectional concept - the persons struggle for doing good things for that organization, such actions that show his or her interest in its goals and values, and the desire to be a part of that organization. Employees' loyalty is often viewed as the attitude towards a particular organization which is the belief in the cohesion between them and their company, the eagerness to stay touched with the organization (Niehoff \& et al, 2001). Loyalty (2004) affirms that employees' loyalty is when employees committed to the success of an organization and they believes that working for this organization is their best option. Employee is loyal to his or her organization when he shows commitment and believes that it is the best option for him or her to work for the organization, he or she decided not to leave and nor any plan to go in some other organization 
(Coughlan, 2005).

According to Rahman et al. (2011), employee loyalty has 5 expressions: (i) have long-term commitment to the organization, (ii) introduce friends and relatives to the organization as a good workplace, (iii) recommend its products and services to friends and relatives with enthusiasm; (iv) feel proud of working in the organization and (v) be willing to work hard and make contribution to the organization's success.

In Vietnam, Nguyen (2012) said that factors measuring the loyalty of bank employees include: change of job, the introduction of new employees to work, the introduction of bank services to acquaintances, pride and effort for the job, work effectively and try to improve efficiency; be dedicated to the bank. Nguyen (2010) conducted a survey with a sample of 528 Marketing employees in businesses in Ho Chi Minh City, following Griffith \& Lusch (2007), and resulted in the loyalty of Marketing staff including 3 indicators: "I will work for a long time with the company I am working in", "I believe that I have a good job at the company I am working in" and "I am very satisfied with my current job at the company I'm working".

The above studies have studied the loyalty of employees, workers who are bank employees, marketing employees, etc. However, there has been no research yet fully researching the the loyalty of accountants in Vietnam. This paper studied the loyalty of accountants because income of accountants is not high compared to that of other industries, while the accountants' duties and requirements of accountants are high.

\section{Research Methodology}

Research subjects: The research subjects of this study are accountants in the FDI firms in Thanglong industrial park, Hanoi.

Qualitative research methodology: We used a qualitative research methodology based on some in-depth interviews with 3 lecturers with extensive experiences in accounting in FDI firms of the National Economics University and University of Labor and Social Affairs. They are the two leading universities in Vietnam in training accounting and human resource management. At the same time, we interviewed 3 experts working as chief accountants in FDI firms. The contents of the interviews focus on the subject of the loyalty of accountants's attributes.

Inheriting the results conducted by Buchanan (1974), Baleman \& Strasscr (1984), Niehoff \& et al. (2001), Loyalty (2004), Coughlan (2005), Griffith\& Lusch (2007), Cooil et al. (2007), Foster et al. (2008), Yee \& Faziharudean (2010), Nguyen (2010), Rahman et al. (2011), Nguyen (2012) and using qualitative research methodology through interviews with experts, we identify the loyalty of accountants including six attributes in table 1 as follows,

Table 1: Attributes of the loyalty of accountants

\begin{tabular}{|c|c|c|}
\hline Code & Scale & Sources \\
\hline \multicolumn{3}{|c|}{ The loyalty of accountants (LA) } \\
\hline LA1 & Have long-term commitment to the FDI firms & $\begin{array}{l}\text { Buchanan (1974), Baleman \& Strasscr } \\
\text { (1984), Niehoff \& et al, 2001, Coughlan } \\
\text { (2005), Griffith\& Lusch (2007), Rahman } \\
\text { et al. (2011), Nguyen (2010), Nguyen } \\
\text { (2012) }\end{array}$ \\
\hline LA2 & $\begin{array}{l}\text { Introduce friends and relatives to the FDI firms as a } \\
\text { good workplace }\end{array}$ & $\begin{array}{l}\text { Loyalty (2004), Coughlan (2005), } \\
\text { Griffith\& Lusch (2007), Rahman et al. } \\
\text { (2011), Nguyen (2010), Nguyen (2012) }\end{array}$ \\
\hline LA3 & $\begin{array}{l}\text { Recommend its products and services to friends and } \\
\text { relatives with enthusiasm }\end{array}$ & Rahman et al. (2011), Nguyen (2012) \\
\hline LA4 & Feel proud of working in the FDI firms & Rahman et al. (2011), Nguyen (2012) \\
\hline LA5 & $\begin{array}{l}\text { Be willing to work hard and make contribution to the } \\
\text { FDI firms's success }\end{array}$ & $\begin{array}{l}\text { Baleman \& Strasscr (1984), Loyalty } \\
\text { (2004), Rahman et al. (2011), Nguyen } \\
\text { (2012) }\end{array}$ \\
\hline LA6 & Pride and effort for the job in FDI firms & Coughlan (2005), Nguyen (2012) \\
\hline
\end{tabular}

\section{Quantitative research methodology}

We have designed a questionnaire consisting of 6 variables with a 5-point Likert scale from 1

"Strongly disagree" to 5 "Strongly agree". The method of data collection was accomplished through the survey and subjects were accountants doing in FDI firms in Thanglong industrial park. We sent 150 questionnaires and received the feedback of 105 . Time to complete is one month. There were 105 questionnaires with full information for data entry and analysis, the size of this sample was consistent with study of Hair et al. (1988): The research sample must be at least 5 times the total number of indicators in the scales. The questionnaire of this study includes 6 indicators, therefore, the minimum sample size to achieve are $6 * 5=30$ observations.

After collecting 105 questionnaires, we cleaned the data and coded the necessary information in the questionnaires. We inputed the data and we used SPSS23 to analyze the data.

The steps of data analysis, as follows 
(i) Descriptive statistics

(ii) Cronbach's Alpha: We assess the reliability of the scale

(iii) Independent T-test and ANOVA

\section{Research results}

\subsection{Descriptive Statistics}

Information of data collected is shown in Table 2

Table 2: Respondents by gender, age, job description, seniority work

\begin{tabular}{|c|c|c|c|}
\hline & Frequency & Percent & Cumulative Percent \\
\hline \multicolumn{4}{|l|}{ Gender } \\
\hline Male & 27 & 25.7 & 25.7 \\
\hline Female & 78 & 74.3 & 100.0 \\
\hline \multicolumn{4}{|l|}{ Age } \\
\hline From 22 to 27 years old & 48 & 45.7 & 45.7 \\
\hline Over 27 years old & 57 & 54.3 & 100.0 \\
\hline \multicolumn{4}{|l|}{ Job description } \\
\hline General accountants & 34 & 32.4 & 32.4 \\
\hline Chief accountants & 34 & 32.4 & 64.8 \\
\hline Accounting staff & 37 & 35.2 & 100.0 \\
\hline \multicolumn{4}{|l|}{ Seniority work } \\
\hline From 1 to 5 years & 37 & 35.2 & 35.2 \\
\hline Over 5 years & 68 & 64.8 & 100.0 \\
\hline Total & 105 & 100.0 & \\
\hline
\end{tabular}

Data in Table 2 show that among the 105 respondents, $25.7 \%$ of the participants were male while the remaining 78 were female, representing for $74.3 \%$. Of these, 48 of them from 22 to 27 years old, accounting for $45.7 \%$; and $54.3 \%$ of the participants were over 27 years old. Among the 105 respondents, accounting staff accounted for $35.2 \%$, general accounting accounted for $32.4 \%$, while the remaining 34 were chief accountant, accounted for $32.4 \%$. Of these, $35.2 \%$ of the participants have from 1 to 5 years and over 5 years accounted for $64.8 \%$.

Table 3: Descriptive Analysis of Attributes of the loyalty of accountants

\begin{tabular}{|c|c|c|c|c|c|}
\hline & $\mathrm{N}$ & Minimum & Maximum & Mean & Std. Deviation \\
\hline LA1 & 105 & 2.0 & 5.0 & 3.810 & .900 \\
\hline LA2 & 105 & 1.0 & 5.0 & 3.848 & .938 \\
\hline LA3 & 105 & 2.0 & 5.0 & 3.838 & .889 \\
\hline LA4 & 105 & 2.0 & 5.0 & 3.876 & .805 \\
\hline LA5 & 105 & 2.0 & 5.0 & 4.086 & .695 \\
\hline LA6 & 105 & 2.0 & 5.0 & 4.143 & .739 \\
\hline $\begin{array}{c}\text { Valid N } \\
\text { (listwise) }\end{array}$ & $\mathbf{1 0 5}$ & & & $\mathbf{3 . 9 3 3}$ & \\
\hline
\end{tabular}

Data in Table 3 illustrate that the respondents agree with the dependent variables of "the loyalty of accountants" where six attributes were quite high with an average of 3.933 compared with the highest of the Likert 5-point scale. All 6 attributes were rated at an average of 3.810 or higher.

\subsection{Cronbach's Alpha}

The loyalty of accountants has been measured by the Cronbach's Alpha with coefficient of 0.703 . Results of testing Cronbach's alpha of attributes are presented in Table 4 as follows,

Table 4: Results of Cronbach's Alpha Testing of Attributes

\begin{tabular}{|c|c|c|c|c|}
\hline & $\begin{array}{c}\text { Scale Mean if } \\
\text { Item Deleted }\end{array}$ & $\begin{array}{c}\text { Scale Variance if } \\
\text { Item Deleted }\end{array}$ & $\begin{array}{c}\text { Corrected Item- } \\
\text { Total Correlation }\end{array}$ & $\begin{array}{c}\text { Cronbach's Alpha } \\
\text { if Item Deleted }\end{array}$ \\
\hline LA1 & 19.790 & 7.610 & .329 & .700 \\
\hline LA2 & 19.752 & 7.361 & .355 & .693 \\
\hline LA3 & 19.762 & 6.260 & .674 & .678 \\
\hline LA4 & 19.724 & 6.490 & .710 & .674 \\
\hline LA5 & 19.514 & 8.445 & .328 & .706 \\
\hline
\end{tabular}

The results also show that attributes of the dependent variables had a Cronbach's Alpha coefficient greater than 0.6; the correlation coefficient of all attributes was greater than 0.3 , so all the attributes of the dependent 
variables were statistically significant (Hoang \& Chu, 2008).

\subsection{Independent $\mathbf{T}$ - test}

Comparing the results of the evaluation of the loyalty of accountants between participants are from 22 to 27 years old and over 27 years old is shown in Table 5.

Table 5: Differences of the loyalty of accountants between participants are from 22 to 27 years old and over 27 years old - Independent Test

\begin{tabular}{|c|c|c|c|c|c|c|c|c|c|c|}
\hline & \multicolumn{2}{|c|}{$\begin{array}{l}\text { Levene's Test } \\
\text { for Equality } \\
\text { of Variances }\end{array}$} & \multicolumn{7}{|c|}{ t-test for Equality of Means } \\
\hline & & \multirow[b]{2}{*}{$\mathrm{F}$} & \multirow[b]{2}{*}{ Sig. } & \multirow[b]{2}{*}{$\mathrm{t}$} & \multirow[b]{2}{*}{ df } & \multirow{2}{*}{$\begin{array}{l}\text { Sig. } \\
(2- \\
\text { tailed })\end{array}$} & \multirow{2}{*}{$\begin{array}{c}\text { Mean } \\
\text { Difference }\end{array}$} & \multirow{2}{*}{$\begin{array}{l}\text { Std. Error } \\
\text { Difference }\end{array}$} & \multicolumn{2}{|c|}{$\begin{array}{l}95 \% \text { Confidence } \\
\text { Interval of the } \\
\text { Difference }\end{array}$} \\
\hline & & & & & & & & & Lower & Upper \\
\hline \multirow[t]{2}{*}{ LA } & $\begin{array}{l}\text { Equal } \\
\text { variances } \\
\text { assumed }\end{array}$ & .219 & .001 & 1.227 & 103 & .023 & .12664 & .10326 & .07814 & .33143 \\
\hline & $\begin{array}{l}\text { Equal } \\
\text { variances } \\
\text { not } \\
\text { assumed }\end{array}$ & & & 1.218 & 96.801 & .026 & .12664 & .10398 & .07972 & .33301 \\
\hline
\end{tabular}

According to the results of Table 5, Sig Levene's Test $=0.001$ less than 0.05 ; the variance between the two from 22 to 27 years old and over 27 years old is different. Moreover, Sig value T-Test $=0.026<0.05$, which means there is statistically significant difference in the level of the loyalty of accountants competence evaluation by workers who have different ages (Hoang \& Chu, 2008).

Comparing the results of the evaluation of the loyalty of accountants between participants are difference about seniority work is shown in Table 6.

Table 6: Differences of the loyalty of accountants between participants are difference about seniority work - Independent Test

\begin{tabular}{|c|c|c|c|c|c|c|c|c|c|c|}
\hline & \multicolumn{2}{|c|}{$\begin{array}{c}\text { Levene's Test } \\
\text { for Equality of } \\
\text { Variances }\end{array}$} & \multicolumn{7}{|c|}{ t-test for Equality of Means } \\
\hline & & \multirow[b]{2}{*}{$\mathrm{F}$} & \multirow[b]{2}{*}{ Sig. } & \multirow[b]{2}{*}{$\mathrm{t}$} & \multirow[b]{2}{*}{ df } & \multirow{2}{*}{$\begin{array}{l}\text { Sig. } \\
(2- \\
\text { taile } \\
\text { d) }\end{array}$} & \multirow{2}{*}{$\begin{array}{c}\text { Mean } \\
\text { Differenc } \\
\mathrm{e} \\
\end{array}$} & \multirow{2}{*}{$\begin{array}{c}\text { Std. } \\
\text { Error } \\
\text { Differenc } \\
\mathrm{e} \\
\end{array}$} & \multicolumn{2}{|c|}{$\begin{array}{c}95 \% \text { Confidence } \\
\text { Interval of the } \\
\text { Difference }\end{array}$} \\
\hline & & & & & & & & & Lower & Upper \\
\hline \multirow[t]{2}{*}{ LA } & $\begin{array}{l}\text { Equal } \\
\text { variances } \\
\text { assumed }\end{array}$ & .441 & .508 & 2.880 & 103 & .005 & .30048 & .10434 & .09354 & .50741 \\
\hline & $\begin{array}{l}\text { Equal } \\
\text { variances } \\
\text { not assumed }\end{array}$ & & & 2.792 & 67.749 & .007 & .30048 & .10761 & .08573 & .51523 \\
\hline
\end{tabular}

According to the results of Table 6, Sig Levene's Test $=0.508$ more than 0.05 ; the variance between the two from 1 to 5 years and over 5 years is not different. Moreover, Sig value T-Test $=0.005<0.05$, which means there is statistically significant difference in the level of the loyalty of accountants competence evaluation by workers who have different seniority work (Hoang \& Chu, 2008).

The results of this study are similar to Rajesh (2004).

\subsection{ANOVA analysis}

ANOVA test helps us perform a comparison for the results of the evaluation of the loyalty of accountants between the three subjects, including accounting staff, general accounting and chief accountant.

Table 7: Test of Homogeneity of Variances

LA

\begin{tabular}{|c|c|c|c|}
\hline Levene Statistic & df1 & df2 & Sig. \\
\hline 2.566 & 2 & 102 & .082 \\
\hline
\end{tabular}

Table 7 shows that Sig Levene Statistic of 0.082 is more than 0.05 ; the hypothesis of homogeneity variance 
among the variable value groups (different job description) has not been violated.

Table 8: ANOVA

LA

\begin{tabular}{|c|c|c|c|c|c|}
\hline & Sum of Squares & Df & Mean Square & F & Sig. \\
\hline Between Groups & 4.052 & 2 & 2.026 & 8.273 & .000 \\
\hline Within Groups & 24.981 & 102 & .245 & & \\
\hline Total & 29.033 & 104 & & & \\
\hline
\end{tabular}

Table 8 shows that, Sig. $=0.000$ is less than 0.05 ; There is statistically significant difference in the level of the loyalty of accountants for the accountant for the mentioned three groups of job description (Hoang \& Chu, 2008).

\subsection{The level agreement with working motivation of accountants}

Table 9: The level agreement with the loyalty of accountants

\begin{tabular}{|c|c|c|c|c|c|c|c|c|c|c|c|}
\hline \multirow[t]{2}{*}{ Code } & \multirow[t]{2}{*}{ Scale } & \multicolumn{2}{|c|}{$\begin{array}{l}\text { Strongly } \\
\text { disagree }\end{array}$} & \multicolumn{2}{|c|}{ Disagree } & \multicolumn{2}{|c|}{ Agree } & \multicolumn{2}{|c|}{$\begin{array}{l}\text { Quite } \\
\text { agree }\end{array}$} & \multicolumn{2}{|c|}{$\begin{array}{l}\text { Strongly } \\
\text { agree }\end{array}$} \\
\hline & & $\mathrm{n}$ & $\%$ & $\mathrm{n}$ & $\%$ & $\mathrm{n}$ & $\%$ & $\mathrm{n}$ & $\%$ & $\mathrm{n}$ & $\%$ \\
\hline LA1 & $\begin{array}{l}\text { Have long-term commitment to the } \\
\text { FDI firms }\end{array}$ & 0 & 0.00 & 8 & 7.62 & 30 & 28.57 & 41 & 39.05 & 26 & 24.76 \\
\hline LA2 & $\begin{array}{l}\text { Introduce friends and relatives to } \\
\text { the FDI firms as a good workplace }\end{array}$ & 3 & 2,86 & 4 & 3.81 & 25 & 23.81 & 47 & 44.76 & 26 & 24.76 \\
\hline LA3 & $\begin{array}{l}\text { Recommend its products and } \\
\text { services to friends and relatives with } \\
\text { enthusiasm }\end{array}$ & 0 & 0.00 & 11 & 10.48 & 18 & 17.14 & 53 & 50.48 & 23 & 21.90 \\
\hline LA4 & $\begin{array}{l}\text { Feel proud of working in the FDI } \\
\text { firms }\end{array}$ & 0 & 0.00 & 5 & 4.76 & 26 & 24.76 & 51 & 48.57 & 23 & 21.90 \\
\hline LA5 & $\begin{array}{l}\text { Be willing to work hard and make } \\
\text { contribution to the FDI firms's } \\
\text { success }\end{array}$ & 0 & 0.00 & 2 & 1.90 & 15 & 14.29 & 60 & 57.14 & 28 & 26.67 \\
\hline LA6 & $\begin{array}{l}\text { Pride and effort for the job in FDI } \\
\text { firms }\end{array}$ & 0 & 0.00 & 2 & 1.90 & 16 & 15.24 & 52 & 49.52 & 35 & 33.33 \\
\hline
\end{tabular}

Table 9 show that:

When asked how much they agree with the attribute "Have long-term commitment to the FDI firms", 7.62\% of responden vote "strongly disagree" and "disagree", the number of respondents "agreeing" is $28.57 \%$ while total of "quite agree" and "strongly agree" contributes $63.81 \%$.

When asked how much they agree with the attribute "Introduce friends and relatives to the FDI firms as a good workplace", $6.67 \%$ of responden vote "strongly disagree" and "disagree", the number of respondents "agreeing" is $23.81 \%$ while total of "quite agree" and "strongly agree" contributes $69.52 \%$.

When asked how much they agree with the attribute "Recommend its products and services to friends and relatives with enthusiasm", $10.48 \%$ of responden vote "strongly disagree" and "disagree", the number of respondents "agreeing" is $17.14 \%$ while total of "quite agree" and "strongly agree" contributes $72.38 \%$.

When asked how much they agree with the attribute "Feel proud of working in the FDI firms", $4.76 \%$ of responden vote "strongly disagree" and "disagree", the number of respondents "agreeing" is $24.76 \%$ while total of "quite agree" and "strongly agree" contributes $70.48 \%$.

When asked how much they agree with the attribute "Be willing to work hard and make contribution to the FDI firms's success", $1.90 \%$ of responden vote "strongly disagree" and "disagree", the number of respondents "agreeing" is $14.29 \%$ while total of "quite agree" and "strongly agree" contributes $83.81 \%$.

When asked how much they agree with the attribute "Pride and effort for the job in FDI firms", 1.90\% of responden vote "strongly disagree" and "disagree", the number of respondents "agreeing" is $15.24 \%$ while total of "quite agree" and "strongly agree" contributes $82.86 \%$.

\section{Conclusion and suggestions for governance implications Conclusion}

The research used the qualitative and quantitative research methods, processed data by statistical method to identify 6 attributes (indicators) of dependent variable "Accountants' loyalty".

Suggestions for governance implications

Have long-term commitment to the FDI firms

Most accountants want to commit to the FDI firms and the amount of time they are working at FDI firms is one evidence to confirm. Accountants feel comfortable and easily communicate with their superiors. However, 
superiors in some FDI firms are not much open, not ready to listen to or discuss problems with accountants. Therefore, superiors should be more close and listen to their employees' opinions.

Accountants have a deep understand and pay attention to the long-term development strategy of FDI firms. Therefore, they will mentally prepare and then, create stronger connections with their careers.

In some FDI firms, accountants do not have the feeling of comfort with their working corner, and consequently, they have no motivation to get to the office. Therefore, FDI firms need to improve the working place for accountants such as light, temperature, etc to create a good condition for them to work effectively and develop their careers.

Introduce friends and relatives to the FDI firms as a good workplace

Accountants feel that the human resources department in their company always support them. Since accountants have learned about the personnel management regulations and human resources department of FDI firms, they can maintain a good relationship with the other staffs in FDI firms.

The size of FDI firms is large and continuously expanding, the production is up to date and the business results are positive. Accountants can acquire professional knowledge about corporate culture and foreign culture, and have the opportunity to learn from the experience of parent company abroad. In addition, FDI firms often offer an attractive salary for accountants. Therefore, FDI firms need to improve their policies on wages, bonuses, and benefits.

Recommend its products and services to friends and relatives with enthusiasm

FDI firms' accountants have deep knowledge of the products and services of their companies, so they can directly do introduce their relatives and friends to the product's functions. And those will become potential customers of enterprises. Therefore, FDI firms need to have incentive policies for accountants in expanding customers by introducing customers to products of businesses.

Feel proud of working in the FDI firms

The business philosophy of FDI firms, which is matching with the value of accountants, has a long-term influence on the engagement and dedication of accountants. Employees see that their personalities, views, and values fit with the corporate cultures and beliefs, and then they feel proud to be part of that organization.

FDI firms always have policies and disciplines to operate human resources. Accountants always attach great importance to corporate discipline, followed by the fact that they always wear uniforms as prescribed, regularly go to work on time, pay attention to deadlines or ask for permission when they leave.

Be willing to work hard and make contribution to the FDI firms's success

Accountants focus on having good performance and answering the question "how to develop their careers", they rarely complain about what they have to do in businesses.

Accountants have a high sense of responsibility and solidarity, they are also aware of what they have to do, or how important of each task that they have to fulfill.

Most of the accounting employees have the good working ability, which leads to motivation for the whole team at work.

Pride and effort for the job in FDI firms

Accountants have a high solidarity, strong teamwork ability with other departments in the company.

They always appreciate the honesty at work, they provide information to appropriate users, and never leak confidential information of the company to the public. However, it doesn't mean that FDI firms do not need to improve their accounting information system to meet the information security requirements.

\section{References}

1. Baleman, T. \& Strasser, S. (1984). A longtitudinal analysis of the antecedents of organizational commiunent Academy of Management Journal, 21, 95-112.

2. Buchanan, B. (1974), "Building Organizational Commitment: The Socialization of Managers in World Organization", Administrative Science Quarterly, 19, pp. 533-546.

3. Cooil, B., Timothy, L.K., Lerzan, A., \& Michael, H. (2007), A Longitudinal Analysis of Customer Satisfaction and Share of Wallet: Investigating the Moderating Effect of Customer Characteristics Journal of Marketing, 71, pp. 67-83.

4. Coughlan, R. (2005), "Employee Loyalty as Adherence to Shared Moral Values", Journal of Managerial Issues, XVII(1), 43-57

5. Foster, C., Whysall, P., \& Harris, L. (2008), "Employee Loyatly: An exploration of staff Commitment levels towards retailing, the retailer and the store", International Review of Retail, Distribution an Consumer Research, 18, pp. $423-435$.

6. Griffith, D.A. \& Lusch, R.F. (2007), "Getting Marketers to Invest in Firm-specific Capital", Journal of Mar/ce//nfif, 71 (January), 129-145.

7. Hair, J.F., Joseph, F.Jr., Anderson, Rolph E., Tatham, Ronald L. and Black, Wiliam C., (1998), Multivariate data analysis, $5^{\text {th }}$ edition, Prentice Hall, Upper Saddle River, NJ. 
8. Hoang, T., \& Chu, N.M.N (2008), Analysis of research data with SPSS, Hong Duc Publishing House.

9. Loyalty, R.C. (2004) Employee Loyalty Measurement, The Loyalty Research Center Press.

10. Nguyen, Q.N. (2012), Determinants influencing the loyalty of bank employees, Journal of Development Economic, No 259, 22-29.

11. Nguyen, T.M.T. (2010), Determinants influencing the loyalty of marketing staff, Journal of Development Economic, No 237, 26-30.

12. Niehoff, 8.P., Moorman, R.H., Bakely, G. \& Fuller, J. (2001), 'The Influence of Empowerment and Job Enrichment on Employee Loyalty in a Downsizing Enviroment", Group \& Organization Management, 26(1), 93-113.

13. Phan, T. T.H. (2016). Improving the quality of accounting and auditing human resources in the integration period, Asian economy in the Pacific, No 4/2016, 43-45.

14. Rajesh, J. B. (2004), A Case Study of Job Satisfaction among Bank Employee of Leading Nationalised Banks of Gujarat State. India, University of Central Arkansas.

15. Rahman, B.A., Mushaireen, M. Harnizam, Z., Razman, R., \& Khazainah, K. (2011). "The Study of Employee Satisfaction and Its Effects Towards Loyalty in Hotel Industry in Klang Valley, Malaysia", International Journal of Business and Social Science, Vo $\backslash 2$ No3, special issue-January 2011, pp.147-155.

16. Yee, B.Y., \& Faziharudean, T.M. (2010), Factors affecting customer Loyalty of Using Internet Banking in Malaysia, Journal of Electronic Banking Systems, 21, pp. 31-57. 